\title{
Correction to: Men's Involvement in a Parenting Programme to Reduce Child Maltreatment and Gender-Based Violence: Formative Evaluation in Uganda
}

\author{
Godfrey E. Siu ${ }^{1,3} \cdot$ Daniel Wight $^{2} \cdot$ Janet Seeley $^{3,4}$. \\ Carolyn Namutebi ${ }^{1} \cdot$ Richard Sekiwunga $^{1}$. \\ Flavia Zalwango ${ }^{3} \cdot$ Sarah Kasule $^{5}$ \\ Published online: 3 April 2018 \\ (C) The Author(s) 2018, corrected publication May 2018
}

\section{Correction to: The European Journal of Development Research (2017)} 29, 1017-1037. https://doi.org/10.1057/s41287-017-0103-6

The article Men's Involvement in a Parenting Programme to Reduce Child Maltreatment and Gender-Based Violence: Formative Evaluation in Uganda written by Godfrey E. Siu, Daniel Wight, Janet Seeley, Carolyn Namutebi, Richard Sekiwunga, Flavia Zalwango and Sarah Kasule was originally published electronically on the publisher's internet portal (currently SpringerLink) on 6 October 2017 without open access.

With the author(s)' decision to opt for Open Choice, the copyright of the article changed on March 2018 to (C) The Author(s) 2018 and the article is forthwith distributed under the terms of the Creative Commons Attribution 4.0 International License (http://creativecommons.org/licenses/by/4.0/), which permits use, duplication, adaptation, distribution and reproduction in any medium or format, as long as you give appropriate credit to the original author(s) and the source, provide a link to the Creative Commons license and indicate if changes were made.

The original article can be found online at https://doi.org/10.1057/s41287-017-0103-6.

Godfrey E. Siu

gsiu@chdc.mak.ac.ug

1 CHDC School of Medicine, Makerere University College of Health Sciences,

P.O Box 6717, Kampala, Uganda

2 MRC/CSO Social and Public Health Sciences Unit, University of Glasgow, Glasgow, UK

3 MRC/UVRI Uganda Research Unit on AIDS, Entebbe, Uganda

4 London School of Hygiene and Tropical Medicine, London, UK

5 Mothers' Union, Anglican Church of Uganda, Kampala, Uganda 